\title{
FLOWERING AND AIRBORNE POLLEN - A NOVEL STATISTICAL APPROACH
}

\author{
Idalia Kasprzyk ${ }^{1}$, Adam Walanus ${ }^{2}$ \\ ${ }^{1}$ Department of Environmental Biology, University of Rzeszów, Rejtana 16c, 35-959 Rzeszów, Poland; e-mail: idalia@univ rzeszow.pl \\ ${ }^{2}$ Department of Geoinformatics, AGH University of Science and Technology, Al. Mickiewicza 30, 30-059 Crakow, Poland
}

Received: 17.08 .2007

\section{S u m m a r y}

The time pattern of flowering significantly affects the pollen season, its beginning, length and the concentration of pollen grains in air. The forecasting models used in aerobiological studies were chiefly based on the elements of weather conditions; however, recently the phenology of pollen shedding has been taken into consideration in these models more and more frequently. The aim of the presented investigations was to determine to what extent the flowering and the occurrence of allergenic pollen grains in air coincided in time. The investigation was carried out in Rzeszow (SE Poland) in the years 2003-2004. The flowering of 19 allergenic plant species was observed and seven phenophases were distinguished. Aerobiological monitoring was based on the volumetric method. In the case of most herbaceous plants, the flowering period overlapped the pollen season, high concentrations of pollen being recorded throughout several phenophases. In general, the pollen of trees occurred during very short periods, frequently during one phenophase, while the investigated phenomena were missing each other. The most intensive growth of inflorescences of alder, hazel and birch was observed at the beginning of full flowering or towards the end of full flowering.

Key words: aerobiology, pollen, inflorescences, phenology, phenophase, flowering, pollen season

\section{INTRODUCTION}

The annual life cycle of plants can be divided into many successive or parallel developmental stages called phenophases. Classic phenological observations associated with modern research techniques (e.g., remote sensing, chemical analyses) offer perfect sensitive methods in monitoring environmental changes ( $\mathrm{S} \mathrm{tu}$ $\mathrm{d}$ e $\mathrm{r}$ et al. 2007). The results of such studies are widely used in numerous fields of science (ecology, biometeorology) and also implemented in the practice of agriculture, tourism, forestry, and medicine. The studies on flowering phenology help in the interpretation of results of aerobiological investigations and also in a more and more precise elaboration of forecasting models of aerobiological processes. It is particularly important in fore- casting the concentrations of allergenic pollen or yields of economically important crops (P h e n o log y ....., 2003; O rla nd i et al. 2005; G a l a n , 2007). In aerobiological studies the forecasting models were chiefly based on climate and the pattern of weather conditions (O r l a ndi et al. 2005). In recent years attempts, have been made to include the biotic factor, i.e. the flowering, in these models. The results show that, depending on the geobotanical character of the investigated region and its climate, the taxonomical level of a given taxon, the location and sources of pollen, these phenomena are more or less connected with each other (J a to et al. 2002; Estre 11 a et al. 2006; S t a ch et al. 2006).

Relevant investigations were most frequently conducted in Spain, Italy and Argentine (L a t to r e, 1999; Fornaciari et al. 2000; Jato et al. 2002). In Poland, K a s p r z y k (2003) was the first to compare the flowering and the occurrence of pollen of selected allergenic plant species. In the work presented here, these investigations have been continued. The basic aim of the work was to ascertain how far the flowering and the occurrence of pollen in air of chosen plant species - important for sensitized people - were overlapping in time.

\section{MATERIALS AND METHODS}

The investigations were carried out in Rzeszów, southeastern Poland, in 2003 and 2004. Aerobiological monitoring was based on the volumetric method using a Hirsttype pollen trap (Lanzoni VPPS 2000) set $12 \mathrm{~m}$ above the ground level. The phenological observations were carried out each year from $1^{\text {st }}$ of January to the end of flowering of the last of the investigated species. The $€ \mathrm{u} \mathrm{k}$ a s z e w i c z (1968) method was used to record the successive 7 phenophases $(F)$ of the generative development of plants:

F1 - the appearance of the first flower or inflorescence buds;

F2 - blossoming of the first flowers;

F3 - beginning of full flowering ( $25 \%$ of flowers open); 
F4 - the first flowers shedding blossom;

F5 - end of full blossoming ( $75 \%$ of flowers shedding blossom);

F6 - the last flower buds;

F7 - end of blossoming (from the day of the last flowers ending blooming to the end of the year).

The observations were conduced at few days' intervals in three study areas characterized by varied environmental conditions. The investigations concerned nine tree species (Corylus avellana L., Alnus incana L. Moench, Alnus glutinosa (L.) Gaertn., Betula pendula Roth, Carpinus betulus L., Salix fragilis L., Fraxinus excelsior L., Juglans regia L. and Quercus robur L.); eight species of grasses (Poa annua L., Secale cereale L., Alopecurus pratensis L., Anthoxanthum odoratum L., Dactylis glometrata L., Phleum pretense L., Poa pratensis L.); and three species of other herbaceous plants (Rumex acetosa L., Rumex acetosella L., Plantago lanceolata L.).

The crucial point of the work was to compare the pattern of occurrence of plant pollen in air with the pattern of flowering. For each distinguished phenophase, the respective total of pollen grains and the average daily number of grains in the phase were calculated. A further step included the calculation of the weighted mean of the phase number and of the weighted variance. The statistical weight of the given phase was the mean number of grains per diem in this phase. Thus, the mean shows in which phase on average pollen occurs in air, while the variance shows the occurrence of pollen in air in one phase (low variance) or the distribution of this process in many phases (high variance). With the aim of evaluating the accordance of the time of flowering periods, the synchronization index (X) was calculated according to the formula proposed by $\mathrm{O} 11 \mathrm{ert}$ on and L a c k (1998). When this index is close to one, it indicates a high level of flowering synchronization. The phenological studies were expanded to include measurements of length of male inflorescences in three selected tree species: C. avellana, A.glutinosa and B. pendula. The length of selected inflorescences was measured at intervals of a few days in the whole period of flowering. The obtained data were used in calculating the rate of inflorescence growth in an appointed time unit (length increase/period).

\section{RESULTS}

The comparison of the pattern of flowering in the observed plants with the occurrence of pollen grains in air allows distinguishing three groups. In the first group, the period of the greatest number of pollen grains corresponded with phenophases 1-2.9 on average, i.e. pollen chiefly occurred in air before the start of flowering in the observed individuals. Such a dependence characterized F. excelsior, C. betulus, J. regia and Q. robur. In the case of most plant species observed, the highest numbers of their pollen were noted during intensive flowering (the average phase 3-4.9). This group includes most grasses, both species of sorrel, small plantain, and some tree species, e.g. A. incana. The third group includes species whose pollen was found in air after the period of intensive flowering of individuals. This pattern of the investigated phenomena concerned C. avellana, S. fragilis and $A$. pratensis. In a few cases, only the course of the investigated phenomena differed in the years (A. glutinosa, $B$. pendula, A. odoratum and D. glomerata).

The value of variance was taken into consideration as a measure of dispersion of pollen among the phenophases and was used in arranging species according to this variance (Fig. 1). The order is not exactly the same in 2003 and 2004; nonetheless, the groups of species attaining very high or very low values of variance are similar in both years. Two groups of species were distinguished. In the first group, there are species whose pollen chiefly appeared in one phenophase and the value of variance is low: $\mathrm{s}^{2}<0.5$. In general, such a situation was found in the case of trees. In the species of the second group, pollen grains occurred at high concentrations throughout several phenophases and the variance was high: $\mathrm{s}^{2}>1$. This situation concerned most herbaceous plants $(R$. acetosa, $R$. acetosella, $P$. lanceolata, D. glomerata, $P$. pratensis, A. pratensis, $P$. pretense; Fig. 1).

The periods of flowering of observed individuals were compared between the sites of the investigation. The similarities were very high, as was confirmed by high numerical values of synchronization indices (average value $\mathrm{X}=0.8$ ). No significant differences were found in the values of these indices depending on the seasons of the year, years, or taxon.

The rates of length increase in inflorescences of A. gutinosa, C. avellana, and B. pendula were not uniform in the investigated period. A repeated increase in the growth rate was observed towards the end of flowering, as illustrated by matching curves of the degree five polynomial (e.g., A. glutinosa 2004). In the case of $B$. pendula, in 2004 the exponentiation function ignores this effect (Fig. 2).

\section{DISCUSSION}

The association of the occurrence of pollen in air and the pattern of flowering is obvious, but not always direct. This is confirmed by the literature (L a t to re, 1999; J a t o et al. 2002; K a s p r z y k, 2003; E s tre 1 la et al. 2006; Stach et al. 2006) and the presented results. Differences between these phenomena result both from their specificity and the research methods. Depending on how the pollen trap was placed, the content of pollen in air did not only concern the town but also the region. In general, the pollen season is longer than 

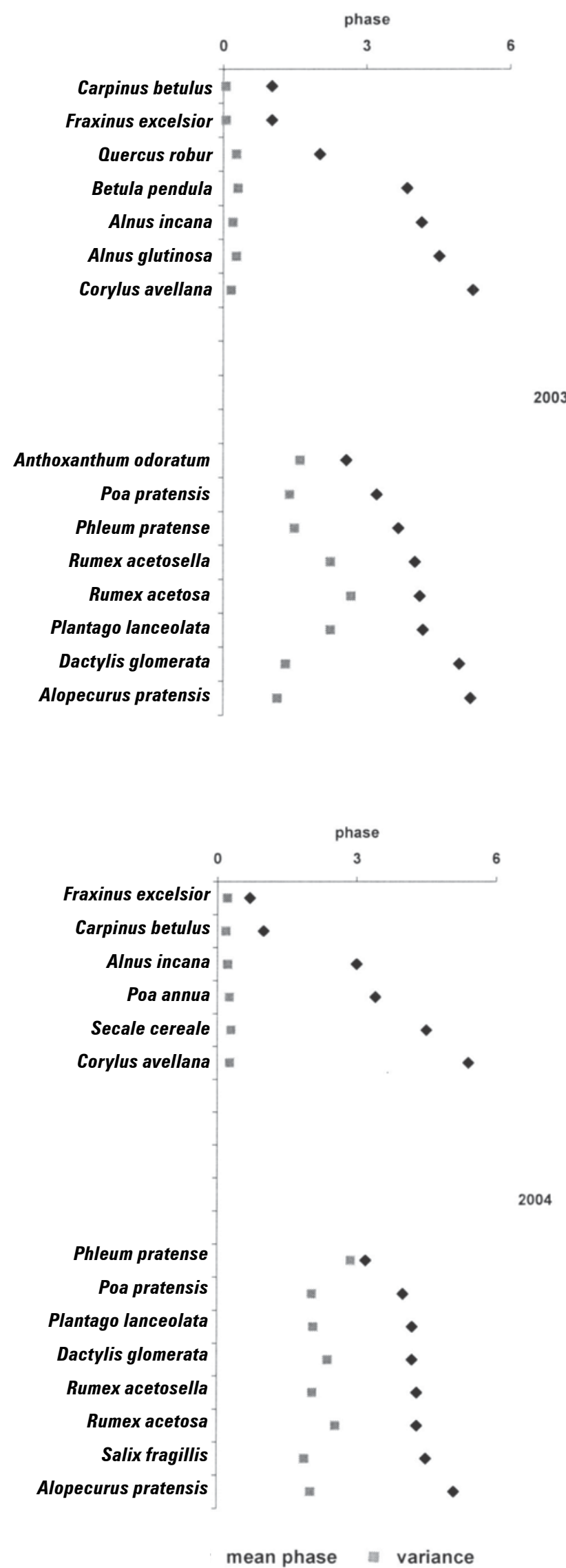

Fig. 1. Species grouped into the low and high-variance class, and then ordered according to the mean phase. 

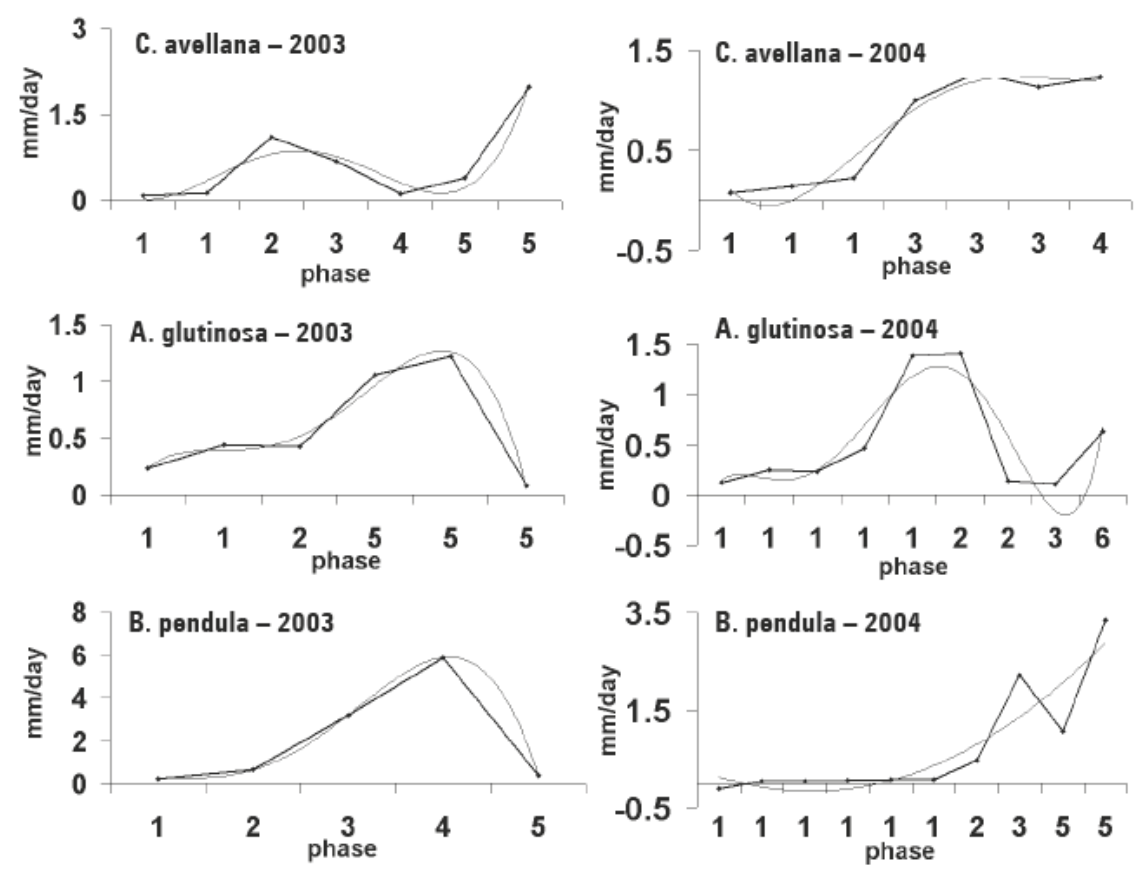

Fig. 2. Rate of inflorescences increase of C. avellana, A. glutinosa, and B. pendula, in 2003 and 2004. It is time on the horizontal axis (with a step of about nine days), however, phenophases are given. The polynomial approximation (thin line) seems to generalize data well.

the flowering period since we take into consideration all pollen grains in air - also these from the secondary fall and from long-distance transport. The pattern of weather conditions has a stronger effect on the length of the pollen season than on the flowering period, the latter being affected by genetic and physiological factors ( $\mathrm{H}$ ä $\mathrm{n}$ $\mathrm{n}$ in e $\mathrm{n}$, 1983). The same species occurring in various plant communities may differ in respect of the time of phenophases. Is it the result of a complex of factors in the given community, reaction to the environmental conditions, different for the population or ecotypes, or whether this phenomenon is genetically determined? (Faliński and Pawlaczyk, 1995).

Of the investigated group of species, one can distinguish those whose investigated seasons missed each other in time in both years. This situation chiefly concerned trees (K a s pr zyk, 2003; Estre 11 a et al. 2006). The trees were flowering in the period of unstable weather conditions and it could have affected the obtained results. High values of the synchronization coefficients show that in the town area the observed species were flowering in similar periods, hence the differences in the time of flowering and occurrence of pollen in air probably resulted from the secondary fall and/or long-distance transport. A part of the recorded tree pollen was probably transported from far regions where the flowering was belated or began earlier. This phenomenon was already recorded in past years (K a s p r z y k, 2003) and in different towns (Estrella et al. 2006). The transport of pollen grains in the atmosphere depends on their shape and the rate of falling out. Pollen grains of many tree species are aerodynamically shaped and remain in air for a long time, increasing the chance of long distance transport (S z c ze p a n ek, 2003).

The description of a group of trees can also show that the period of flowering of these species and even the time of occurrence of pollen grains in air were very short. Species of this group are among those with the lowest value of variance, showing that the greatest amounts of pollen were noted in one phase. In favorable environmental conditions, the inflorescences rapidly elongate and open, however not all at the same time. The observed phenomenon of a repeated increase in the rate of elongation of the inflorescence axis is most probably due to the effect of development of the last flowers on the apical axis.

Most species of herbaceous plants are flowering when the weather conditions are stable and only extreme conditions could disturb this process (Hänninen, 1983). Compared with trees, their pollen is released at a much lower height; it cannot get to higher layers of the atmosphere and theoretically its chance of long-distance transport is lower. This factor and also the biology of flowering affected the high accordance in time of pollen seasons and time of flowering. It should be stressed that pollen of herbaceous plants did not occur only in one phase. It was usually noted in the entire period of intensive flowering (F3-F5) and that is why these species usually show high values of variance.

\section{Acknowledgements}

Authors thank Ms. Smotryś and Mr. Kraska who made the phenological observations. 


\section{REFERENCES}

Estrella N., Menzel A., Krämer U., Behrendt H., 2006. Integration of flowering dates in phenology and pollen counts in aerobiology: analysis of their spatial and temporal coherence in Germany (1992-1999). Int. J. Biometeorol. 51: 49-59

Faliński J. B., Pawlaczyk P., 1995. Zarys ekologii. [W:] Jesion. Fraxinus excelsior L. W. Bugała (ed.), PAN, Wyd. Sorus, Poznań-Kórnik [Outline of ecology. In: Fraxinus excelsior $\mathrm{L}$.

Fornaciari M., Galan C., Mediavilla A., Dominguez E., Romano B., 2000. Aeropalynological and phenological study in two different Mediterranean olive areas: Cordoba (Spain) and Perugia (Italy). Plant Biosystems, 134 (2): 199-204.

Galan C., 2007. Recent phenology methods applied to aerobiology. [In:] AEROTOP Workshop. Phenology, forecasting and airborne allergens. 18-20 $0^{\text {th }}$ May, Poznań. pp.1-13.

Hänninen H., 1983. A method for identifying the flowering season from aerobiological data. [In:] Nordic Aerobiology. 5th Nord. Symp. Aerobiol. Sweden. pp. 51-57.

Jato V., Méndez J., Rodríguez-Rajo J., Seijo C., 2002. The relationship between the flowering phenophase and airborne pollen of Betula in Galicia (N.W. Spain). Aerobiologia, 18: 55-61.

Kasprzyk I., 2003. Flowering phenology and airborne pollen grains of chosen tree taxa in Rzeszów, SE Poland. Aerobiologia, 19: 113-120.

Lattore F., 1999. Differences between airborne pollen and flowering phenology of urban trees with reference to production, dispersal and interannual climate variability. Aerobiologia, 15: 131-141.

Łukaszewicz A., 1968. Potrzeba ujednolicenia metodyki fenologicznej w polskich ogrodach botanicznych i arboretach. / The need to standardise the phenological method in Polish botanical garden and arboreta. Wiad. Bot. 28: 153-158.

Ollerto n J., Lack A., 1998. Relationships between flowering phenology, plant size and reproductive success in Lotus corniculatus (Fabaceae). Plant Ecology, 139: 35-47.

Orlandi F., Vazguez L. M., Ruga L., Bonofiglio T., Fornaciari, M., Garcia-Mozo, H., Dominguez E., Romano B., Galan C. 2005. Bioclimatic requirements for olive flowering in two Mediterranean regions located at the same latitude (Andalusia, Spain, and Sicily, Italy). Ann. Agric. Environ. Med. 12: 47-52.
Phenology and human health: allergic discorders. Raport on a WHO meeting Rome, Italy, 16-17 January 2003.

Stach A, Kluza-Wieloch M., Zientarska A., 2006. The phenology of flowering and fluctuations of airborne pollen concentrations of selected trees in Poznań, 20032004. Acta Agrobot. 59 (1): 301-308.

Studer S., Stöckli R., Appenzeller C., Vidale P.L., 2007. A comparative study of satellite and ground-based phenology. Int. J. Biometeorol. 5: 405-414.

Szczepanek K., 2003. Wytwarzanie i rozprzestrzenianie spor i ziarn pyłku. [In:] Palinologia. S. Dybova-Jachowicz, A. Sadowska (ed.), Wyd. Inst. Botaniki PAN, Kraków. pp. 16-28 [Production and release of spores and pollen grains. In: Palynology].

\section{Kwitnienie a występowanie pyłku w powietrzu - nowe statystyczne podejście do problemu}

\section{Streszczenie}

Związek pomiędzy występowaniem pyłku w powietrzu a przebiegiem kwitnienia jest oczywisty, lecz nie zawsze ścisły. Celem pracy było określenie na ile pylenie i występowanie pyłku wybranych gatunków roślin w powietrzu pokrywało się $\mathrm{w}$ czasie $\mathrm{i}$ w latach. Prowadzono monitoring aerobiologiczny metodą wolumetryczną oraz obserwacje pylenia 19 gatunków roślin w latach 2003-2004. W przypadku drzew okresy pylenia i sezony pyłkowe na ogół rozmijały się w czasie. Najwięcej pyłku notowano w jednej fenofazie, przed lub po okresie intensywnego pylenia. Na wszystkich powierzchniach badawczych osobniki kwitly w podobnym czasie, stąd można przypuszczać, że pyłek występujący w powietrzu poza okresem intensywnego kwitnienia mógł pochodzić z dalekiego transportu lub opadu wtórnego. Pyłek roślin zielnych występował w powietrzu w okresie najintensywniejszego pylenia przez kilka fenofaz. 
